\section{Democracy, Democracies and Democracy Discourses in Nepal: An Anthropologist's Engagement}

\section{Suresh Dhakal}

\begin{abstract}
Democracy is conceptualized and practiced differently in different times and places; and may exist in various forms and levels with various degrees and dimensions. Therefore the use of the word "democracy" occurs neither alone, nor steadily, nor completely; it is, "historically" and "ethnographically emergent". Following an extensive review, the paper concludes that democracy (ideals, institutions and practices) is depended upon effective state vis-à-vis strong civil society. Effectiveness of the state and the strength of the civil society, both depend on a common denominator, that is, participation. This paper, excavates some of the traces of, what we may like to refer today as democracy, in our own historical context; and, portrays how the meaning of democracy shifting along with the shifting of the local terms for democracy.
\end{abstract}

Keywords: democracy, CBO, public sphere, participation, ethnography

\section{Democracy or Democracies, Locating the Context}

There is not a single, universal 'democracy' across time and space. Democracy is conceptualized and practiced differently in different times and places. Democracy may exist in various forms and levels with various degrees and dimensions. Ideals and practices may vary along with time and space. Therefore, studying democracy becomes illusive' if one claims to study it in its 'totality' (Schemeil, 2002); rather one can study some dimensions and/or aspects of democracy in a given time and space context.

In his book, Democracy and Despotism in Primitive Society: A Neo-Weberian Approach to Political Theory', Glassman (1986) discusses the democracy in Hunting-Gathering, Hunting-Horticultural or Herd-Hunting Tribes, and he calls it a 'Primitive Democracy'. Alam (2004), in his popular work, Who Wants Democracy, illustrates the plural forms of democracy and suggests looking into 'democracies' but not 'the democracy'. Similarly, Irish Young, who is known for her activism and academic image, in her book Inclusion and Democracy, writes, "Democracy is not an all-or-nothing affair, but a matter of degree; societies can vary in both the extent and the intensity of their commitment to democratic practice" (p. 5). And, she argues for 'deep democracy'. Similarly, Hans Joas (1996) in his wellread book, The Creativity of Action, talks about 'creative democracy'. Hence, these works suggest us to take a different path from the contemporary political theory, which revolves around the 'two models of democracy, called aggregative and deliberative' (Young, 2000, p. 18). Therefore, we begin our study with the assumptions that democracy can be studied better with its 'specific ethnographic context' (Paley, 2002), as democracy can neither be studied in its totality or without any specific context.

Authors in an edited volume, Democracy: Anthropological Approaches, have more pronouncedly argued that democracy is grounded in specific historical experiences and cultural assumptions therefore urged to search for a specific definition of democracy or 'celebrate alternative democracies' (cf., Paley, 2008). In the same volume, Banarjee (2008) tries to examine 'aspects of democracy in its various settings of everyday politics' (p. 63), furthering the idea of understanding democracy with specific historical experiences of the people and cultural assumptions.

However, there have not been any substantial efforts to understand and analyse democracy in the context of Nepal with an 
ethnographic approach. Such studies, had there been any, could have provided us the local specific perspectives in order to understand how democratic a society is.

In this article, I review the historical processes and contemporary practices that provide a wider space to explore and analyse the discourses on democracy in Nepal. The major efforts would be to look into the particular historical context and to move away, to the possible extent, from the dominant discourses of democracy often engaged by the political scientists through the anthropological engagements.

\section{Democracy in Retrospect}

Nepal's tradition of collective action, civic engagement, community based public spheres are dated back even to traceable history, for example as in the form of and described by dharma (institutional duties and roles) shastras (moral and legal treaties) and shastartha (philosophical discourses), were some of basic regulatory principle that allowed people to engage in 'civic life' (Dahal \& Timsina, 2005). Institutions and traditions like, Gurukul (voluntary residential school), Guthi (trust), Parma (labour exchange) were some other forms of collective actions and for a, which are dated back to time unknown but are continued even today, in modified forms, though.

Nepal's 'historical' era begins with Lichhavi Period (100-880 AD). Changu Narayan inscription of Lichhavi King Manadev I (464 AD) is recognized to be the first written evidence of Nepalese history. Three significant features of this period were the beginning of the land taxation; trade, political and cultural relations with Tibet and India; and village autonomy practiced through Panchali: 'group of people closely living and cooperating within the village, bound together by common economic, social and ritual ties' (Sharma, 2004, p. 50), also called as gram kutumbi. This is the first ever historically traceable record of social networks and trust based on reciprocal relations, which I will refer as a form of Community Based Organisation (CBO). Nevertheless, such Panchalis were formed to establish a 'centralised control of the village' (Sharma, 2004, p. 50). The central control over the Valley apparently weakened and the Lichavis came to decline during the eighth century. Until the middle of the eleventh century dvairajya (simultaneous rule by two individuals) was common' (Whelpton, 2005, p. 19). The later years of Lichhavi periods, particularly after the Pashupati inscription (733 AD) of Jayadev II, is considered to be the 'dark age' in the history of Kathamndu valley, the then Nepal Upatyaka (Sharma, 2054 BS, p. 8). It was particularly due to the unavailability of historical documents pertaining to that period.

In Malla period (1200-1768), further consolidation of Guthi, as there are several evidences of existence of Guthi before the Mallas (Sharma, 2054 BS), can be taken as an example of consolidation and continuation of collective works and cooperation. In both the cases, not only concept of CBO (in the forms of panchali or guthi) got popularised and institutionalised but the 'notion of private property was defined by keeping within a lineage or a named group' (Whelpton, 2005, p. 83). In addition, there were other traditionally hosted indigenous organizations such as Gurukul, voluntary residential school (Dahal \& Timsina, 2007); Bheja among Magars (Dhakal, 1996), Pareli or Porima, labour exchange (Messerschmidst, 1974; Messerschmidt \&Gurung, 1973); Khyala among Tharus (Bellamy, 2009; Dhakal \& Chemjong, 200), which were existed and continued over the generations. Such traditions were not only maintained the cultural identities of different groups but also were the indigenous forms of governance (c.f., Bhattachan, 1997).

However, unlike in previous years, '[l]and tenure and land practices of the Medieval Period thus underwent significant changes in their character, affecting the socio-economic, cultural and political lives of the people in more ways than one' (Whelpton 2005, p. 83). In the case of Guthi in particular, it provided a 'fundamental point of identity to Newars in terms of their social lifestyle, an identity that far transcends its land-based character' (Sharma, 2004; and 2054 BS).

Likewise, a far-reaching institution instituted during Malla Period by Jayasthiti Malla, by the end of $14^{\text {th }}$ century was the social reforms and 
caste re-organisation. He is also said to have initiated the system of land classification, dividing land into four categories based on their productivity; and introduced several changes in land administrations (Sharma, 2004).

Outside of the valley, before the conquest of Shahs of Gorkha, (1679) 'there was a network of statelets emerged in the western and central hills, particularly after the Khasa empire fragmented around the beginning of the fifteenth century' (Whlepton, 2005, p. 23). Then, Karnali basin was popularly known as the baisi rajya ('twenty two principalities') and in the Gandaki basin as the chaubisi rajya ('twenty four' principalities). Hence, those principalities and the Kathmandu Valley, which would later formed a nation state Nepal, were of various origin and contexts in terms of migratory history, economy, society and culture.

Joanna Pfaff-Czarnecka (1997) captured the major efforts to accommodate Nepal's varied cultures in the course of three subsequent political epochs and examines the related processes of cultural changes. And, she distinguished three different model of national integration. They were $i$. the empire model, ii. the nationalistic model, and iii. the patchwork of minorities model (PfaffCzarnecka, 1997, pp. 421-423).

The establishment of the centralised nation state by Prithvi Narayan Shah, King of Gorkha, by conquering Kathmandu valley in 1769 and subsequently the other smaller principalities begins a new history in the country; considered as the beginning of the modern history of Nepal. Since then the entire Shah and Rana regimes (between 1769 and 1951) made their efforts to centralise and to expand their polity, created a 'Hindu state' combining diversity with hierarchical organisations and the plurality of Nepalese society was conceived of within a uniform socio-political framework'. Then 'citizens' were not asked to participate in the process of national identity formation (Pfaff-Czarnecka, 1997). A key question for historians and also a burning issue in present-day politics, as Whelpton (2005) asks remains 'how far the territories brought under
Gorkhali control achieved a sense of common identity and how far they remained simply conquered territory?'(Whlepton, 2005, p. 55).

\section{The Rana Period}

Even during the Rana period (1846-1951) the expansion of the centre's effective political control over remote areas, the centralisation of taxation system, and rationalization of the land-tenure and taxations system got intensified. However, promulgation of first Nepalese Legal Code (Muluki ain) in 1854 said to have inspired by Western emphasis on codification (Pfaff-Czarnecka, 1997), but devised by the Parbate elites has been the mainspring of ‘social exclusion' (Gurung, 2004) in Nepal seem to have an enduring effect. Hofer observes: "In Muluki Ain, the conspicuous indifference towards most of the ethnic groups was justifiable by ignorance and the unchallenged political dominance of the higher Hindu castes. The MulukiAin "accommodated" the nation's diversity into caste hierarchy, legitimating social inequality as being in line with dharma. Present day legislation, by contrast, proceeds from the fiction that this diversity implied only in difference in the field of custom and religion (Hofer, 1979).

Through the centralised taxation system based on privatizing land tenure system, imposition of corvee labour birta land grant practices, the aristocracy appropriated the meagre surplus of the peasants and removed them from their land throughout the nineteenth century (Regmi, 1976). On the other hand, during the same period, the loss of the land of indigenous groups, which was the basis of their subsistence livelihood, led to loss of their history, culture and identity (Lama, 2004).

The oligarchic Rana regime created a wide public discontent. Civic society and forum, which were not political parties but had distinct political implications, had come into existence. Prominent examples of which were Arya Samaj (civic society); Prajatantra Sangha (Democratic Association) founded by Prem Bahadur Kansakar, and Paropakar Samsthan (Charity Association) founded by Daya Bir Singh Kansakar, who are widely recognized as social 
reformers. These had apparent political implications and were move towards democratization process, and cumulative effects of which strengthened the formation and activities of political parties and as a result the King and the political movement succeeded in negotiating a formation of the Rana-King-Nepali Congress coalition government in 1951. But this tri-partite coalition was beset with difficulties from the start; however, this coalition was able to promulgate the interim Constitution of Nepal for the first time in its history, which separated the executive, legislative, and judiciary function of the state (Agrawal, 1976, quoted in Lama, 2004). This was a substantial change in the organisation of the government towards modernisation. This gradually opened possibilities for participation to ascending section of the Nepalese society and scribal elites in the state apparatus. Thus, for the first time in its modern history, Nepal encountered and experienced some democratic ideals and institutions.

\section{After the Ranas and the Panchayat System}

Eventually in 18 Feb 1959, first ever election for the parliament was held, in which Nepali Congress Party won the majority (67.2\%) of seats in the parliament and formed the government under the premiership of B.P. Koirala. This could not last long. On 15 December 1959, the King Mahendra used the emergency power, granted by the 'constitution' to terminate the majority government of Congress Party led by strong-willed prime minister; and, banned the political parties. After this royal takeover, which was 'achieved without initial opposition' (Whelpton, 2005, p. 99), the King introduced a new "party-less Panchayat Democracy". Under the Panchayat system, a national assembly (Rastriya Panchayat), a parliament of sorts with members nominated and elected on individual basis was created; which was dominated by the segments of society that were loyal to the King with high ritual status and landed property. In 1963, similar Panchayat or assemblies were created in the district and village levels by setting 75 districts and 14 zones as politicaladministrative units within the country. To be elected in any tire of
Panchayat, membership of any Bargiya Sangathan (class based organisation) was mandatory. Such organisation, in fact, helped to 'tap the local traditional political authorities and act out decentralised the posture effectively' (Lama, 2004).

The constitution of 1962, although having progressive appearance, was handled by the expanded sovereign authority of the King. The essence of the party-less system was the absence of popular participation and centrality of the King. Under the "Panchayat Democracy" the King skilfully managed to combine the two sources of legitimacy - the traditional Hindu kingly authority and the modern notion of representative democracy (Bleie, 2002). Nonetheless, people exercised their franchise throughout the Panchayat regime.

Nepal, during this period was gradually integrating to the rest of the world. Development, therefore, was the central promise made by the Panchayat regime. In order to implement programs, bureaucracy was expanded to the fullest extent possible under sponsorship of international donors. The expanded state institutions of bureaucracy along with the aid sector largely incorporated educated members of the middle class families mostly from hill Brahmins, Chhetris and some high caste Newars.

Some of the programs launched by the Panchayat, which could have impacted Nepali society to a greater extent could not be implemented (or was not possible to implement in the given administrative strength) as intention, viz. Gaun Farka Rastriya Abhiyan (Back to Village National Movement), Land Reform Act (of 1964), Sana Kishan Bikash Karyakram (Small Farmers Development Project), Decentralisation Act, arguably a concrete step to devolve the power to the local authorities (c.f. Pfaff-Czarnecka, 1997; Pandey, 1999).

The Panchayat system, however, largely succeeded in its 'assimilation policy', insisting upon creating a homogenous 'development' society (Pfaff-Czarnecka, 1997). "During the Panchayat period, the cultural language of the dominant Hindu groups emerged as the language of modernisation (italics in original). Since the high-caste elites were able to establish themselves as brokers 
between international allies/donors and Nepalese society, they could claim that 'their' cultural symbols and means of expression were successful means of progress in the national context" (PfaffCzarnecka, 1997, pp. 435-36).

\section{Restoration of Democracy a-Post 1990 Discourse}

The national and international context was growing against the favour of autocratic or non-democratic regime. Eventually, the people's movement against the party-less Panchayat system in 1990 restored the 'democracy', and new democratic Constitutions 1991 came into being. This restoration of democracy and the promulgation of new constitution in the country not only marked with the 'shifting of sovereignty from King to the people, but also declared the Kingdom to be multi-ethnic and multi-lingual, which was a 'drastic departure from the governmental measures aimed at the homogenization of Nepalese society during the preceding decades' (Pfaff-Czarnecka, 1997).

Now the discourses emerged soon on democratic practices. Party system throughout the political structure, election on all level, in the absence of internal democracy within mainstream political parties, the latter became more and more dependent on national level leaders to secure their own position in local politics (even the selection of the candidates for VDC elections was done by party leader in Kathmandu, therefore, local political leaders had to remain highly dependent on national-level leaders for their own political fortune (Bhabishya). This eventually weakened the demanding/bargaining power of the local leaders for greater autonomy and resources, and local issues got less priority. This scenario was definitely not conducive for local level democracy and effective functioning of local bodies: of the mainstream political parties and thereby the local level government bodies and functionaries.

However, massive development efforts; I/NGO and Government's development strategy demanding to be more participatory giving rise to a numerous local groups in order to make programs more sustainable by securing more peoples participation and ownership created sufficient space for people participate in various development and consequently in political processes.

\section{Maobadis and 'Peoples War'}

Amidst local dissatisfaction but growing aspiration of the people, the then Nepal Communist Party of Nepal (Maoists) initiated an armed struggle against the state; they called it 'peoples war'. The insurgency weakened and marginalised the local level democratic institutions, formally, government bodies; traditional institutions and interest groups were eventually deteriorated. In the meantime government attempted to bring about several constitutional changes in order to offer a greater autonomy, and mainstreaming/inclusion of the excluded groups. Eventually, on October 4, 2002, the elected Parliament was dissolved. And the King assumed all the state power on February 1, 2005. Paradoxically, King, to justify his act, argued that 'democracy should be for the country', the country was in the 'verge of collapse', therefore, he had to take such a 'bold step', etc.

In 2008, following the popular mass uprising, the election of the Constituent Assembly (CA) took place successfully, which established Maoist, a party that waged the armed struggle in the country from 1996 to 2006, a largest party in the constituent assembly. The CA declared Nepal a 'republic', and with the ousted of the King from the Palace also ended the long reigned history of monarchy from Nepal.

Maoist insurgency (1996-2006) has remained a significant historical fact in Nepal's recent history, for both its sympathisers and its critics. I find it quite relevant to explore the linkages between the functioning of democracy after its restoration in 1990 and Maoist insurgency after 1996 in the country. There has been a dominant discourse, which invokes that democracy failed in democratic inclusion of all castes, creeds, gender, and ethnic minorities (Thapa and Sijapati, 2003, Dhakal et.al, 2004). 
Amartya Sen argues that there is a higher chance of an equitable distribution of resources and benefits with a democratic government than without one (Sen \& Dreze, 1999). Limiting the input side to the regular holding of elections, it can be argued, is too limited, as it leaves out associations and organisations advancing and negotiating their material interests as for instance do trade unions. Therefore, any reasonably wide definition of democracy and of its inclusiveness would have to take account of not only ideals and institutions but also of practices or, inputs as well as outputs. The inputs, or the policy makers, shall have to be representative of public opinion as guaranteed by regular elections, and the outputs, or the policies, shall have to be inclusive in ensuring the widest possible coverage of its resources and benefits. If the inputs are nonrepresentative and the outputs non-inclusive, then clearly there are democratic deficits and reduced trust and confidence in the efficacy of the political system. Such reduced trust may give rise to anti-systemic political forces which over time may represent a threat to the viability of the system (Lama, 2004).

Hence, it is useful to discuss the inputs to the democratic process in Nepal though local experiences, they are, (a) assessing public opinion through voting patterns in elections; (b) assessing democratic inclusion by examining the composition of elective bodies and the degree to which the elected are representative of their voter constituencies and (c) assessing democratic inclusion in local politics (Kramer, 2003; Gellner, 2003; Kahanal, 2004; Lawoti, 2005, and Whelpton, 2005).

Among several others, Liz Philipson (2002), Karki \& Seddon (eds. 2003), Thapa (ed. 2003), Thapa and Sijapati (2003), Dhakal et.al. (2003), and Mishra (2004), have outlined the chronological events and emergence of the Maoist insurgency from different perspectives. This article does not deal them in detail here, though. Among the possible explanations for the conflict, it has been widely assumed and argued that social exclusion has been central in contributing to the conflict (Kumar 2005; Neupane 2003; Lama 2005, Mishra 2005; Bhattachan 2005). However, it is always useful to distinguish between underlying structural sources of the conflict, and what may be called contingent or triggering variables.

In the first category are economic, social and political structures of poverty, inequality, domination and legitimacy on a nation-wide level, and the extent to which these are stable or changing (systemic "stress"). A very few literature distinctly deals with this perspective, viz., 'Inside the revolution in Nepal' by Pushpa Kamal Dahal; 'The Political Economy of the People's War' by Baburam Bhattarai; 'The Maoist Movement in Nepal: A Class Perspective' by Govinda Neupane (all three articles included in Karki \& Seddon (eds.) 2003); and, Chaitanya Mishra in latest work 'Locating the Causes of Maoist Struggle' published in Studies in Nepali History and Society (2004), among others. All these literature, however, do not fail to underline the exclusion of various levels and forms in political, social and economic spheres as the structural cause of the insurgency. However, large corpus of literature merely deals with other contingent and triggering variables relating to organizational and individual level of response and mobilization. However, it is sociologically and historically, too, once cannot simply overlook the fact shaping individual decisions and forming collective action is also equally significant in to violently oppose the state (Dhakal, et.al. 2003). However, macro level understanding will be substantiated or refuted by micro level cases studies by elaborating our understanding of mechanisms of exclusion by concretizing structures and processes of exclusion at the individual, household and community.

\section{From Prajantara to Loktantra}

While discussing that democracy in the local level refers to a particular process of people's engagement in collective activities. However, I will begin the discussion on how democracy has been understood or interpreted over the years in the general. 
Webster's Encyclopaedic Unabridged Dictionary of the English Language $^{1}$ (1996) defines democracy as “... a form of government in which the supreme power is vested in the people and exercised directly by them or by their elected agents under a free electoral system ..." However, a value-laden concept like democracy empirically may mean different things to different people. A recent survey, State of Democracy in Nepal (2004), reveals that 'democracy is still an elusive concept to most of the common Nepalese.

According to that survey, 51 percent of the respondent equated democracy with the concepts like 'freedom, equality and liberty', some understood it as 'principle' (23\%), and for others, it was a mere but a 'popular term' (21\%). Similarly a few related the term democracy with 'institutional process' (5\%); 'peace and stability' (4.5\%); basic needs' (4.5\%); 'justice' (2\%); and 'structuring (1\%). At the same time, 10 percent of the respondents also equated it with negative attributes (Hacchethu, 2004). A 45 percent of the respondents of the survey were illiterate. Nevertheless, the majority of the respondents (51\%) maintained that the opportunity to change the government through election, and for a substantial portion of the respondents (31\%) equal rights for everyone are the most essential to democracy (Ibid). Thus, in an aggregate, democracy is related with rights of people to participate in decision-making process.

At a theoretical level, the discourses labelling certain kind of practices and regimes as democracies are strategically deployed by a number of powerful groups with strong interest in particular definitions and contested by others differently situated in relations of power (Paley, 2002, p. 471). In Nepal's experience, as Lama (2004) argues, “... the interests of feudal aristocracy and 'high' caste Parbatiya group comprise a major force in shaping such discourse locally. The practice emanating from such hybrid understanding of democratic ideals has tended to protect and promote privileges of traditional elites and disguise exclusion and further marginalize

As dictionary meaning is considered to be a layman term, without any disciplinary jargon, and commonly understood by ordinary people. indigenous peoples, Dalit ${ }^{2}$, women and other minorities in the country" (Lama, 2004).

At this point, the link between the state and democracy is projected for the counters to the former arguments that it is states that destroy democratic institutions. States being notoriously willing to curtail democracy, therefore, society, and preferably a strong civil society, is needed as a bulwark against these potentially authoritarian tendencies (Jayal, 2001).

For common Nepalese, which is not a homogenous lotculturally and ideologically- the term democracy may not have

"Dalit" is a term first coined by Dr.B.R.Ambedkar, one of the architects of the Indian Constitution of 1950 and leader of the Dalit movement. It was taken up in the 1970s by the Dalit Panther Movement, which organsied to cliam rights for "untouchables", and is now commonly used by right activists. In Nepal, the term "Dalits" instead of "untoucahbles" and "lower cste" was brought into everyday use by right activists, after 1990, in particualr. However, the use of the word has been contested within the group. Some Dalits are of the opinion that "Dalits" refer to a particualr state of socio-economic and cultural condition, therefore, Dalits will remain no longer Dalits once they are empowered and achieve the status of other "high caste" people. Therefore, we should not stick in the term as a universal category. However, in my writing I will be using the term Dalits, who otherwise are referred as "low caste", "untouchables" in social sceince literature. Sometimes, the term "sceduled caste" has also been used to refere the same categoreis of pople, however, not in common use and not accepted as the appropraite in Nepaslse context. The term "scheduled caste" comes from Indian contextm whihc refers to a list of socially deprived ("untouchables") castes prepared by the Britishc Government in 1935. The schedule of caste was intended to increase representation of scheduled-caste members in the legislature, in government employment, and in university placement. The term is also used in the constituions and in various lawas. Similarly in India, the term "scheduled tribes" referes to a list of indigenous tribal populaiton who aer entitled to much of the same compensatory treatment as scheduled caste. In Nepalese context, though the terms are sometimes used "ignorantly" or simply drawing from Indian texts, these terms are not recognised in social science literature. 
meaning independent of the context. Meaning of democracy may vary depending on class, caste, ethnicity, and geographical locations. Therefore, one may find a variety of meaning exemplified associated with democracy. However, to follow the dominant discourses, it tended to imply for and against certain types of regimes and governance for last seven decades. Towards the end of the Rana regime (1846-1951), democracy was understood as something against or different from Rana oligarchy. With the end of Rana rule (1951), democracy or Prajatantra(rule of the subjects) is supposed to have been introduced in Nepal. The first decade (1951-1960) of democracy was to do with freedom of speech and behaviour, while it also maintained the anti-communist essence. In 1961, King Mahendra banned all the political parties and established the Panchayat system of rule. As the ideology of Panchayat system gradually developed under the leadership of an active monarch, it was promoted as "Panchayat Democracy." The Panchayat Democracy supported oneparty state and was not considered as the dismissal of democracy; rather it was taken as a rejection of "foreign ideology" of political parties in favour of substantive democracy through guided mechanism. However, during the entire Panchayat period (19611990), democracy remained as something against Panchayat system. Those who were against Panchayat and were not communist were recognised as Prajatantrabadi (democrat) by the general public. After the people's movement of 1990, again democracy referred to what Nepali Congress wanted the people to vote for, though the system prevailing was called as 'multi-party democracy' or 'parliamentary democracy'. The system of multi-party parliamentary democracy is understood to include the ability to accommodate a number of political groups belonging to different ideological orientations. The Nepali Congress Party is one of the major players in the system, which started off with the goal of establishing "social democracy." The Communist Party of Nepal (Unified Marxist-Leninist) promoted "People's multi-party democracy" or "Janata ko bahudaliya janabad" and participated in the parliamentary system. The then Communist Party of Nepal (Maoist), who wagged the 'Peoples' War' on the other hand rejected the multiparty parliamentary democracy as a bourgeois institution and claimed to achieve republic "New People's Democracy."

The Royal takeover of the state power in October 2002, suggests yet another possible variant which may be called democracy with “constructive monarchy”. After February 1, 2005, a new term emerged as sarthak prajatantra (the meaningful democracy) advocated by the King and his people, at the meantime, the term democracy connoted the collective aspiration of major political parties against King's move. They began to call it as Loktantra. After all, the Nepalese experience of democracy pertaining to different times has suffered from the limitation of interpreting democracy primarily as a regime form of the state or a principle of representative government, rather than as a way of constituting collective life in society.

Bhattarai (2004) narrates in his recent article, what people think about democracy (and the moral burden it carries) today has strong roots in how the very word got established in Nepali society. According to him, 'three major processes have perhaps had the most far reaching impact on the formation of the idea of democracy in Nepal. The first is the process of implantation of the 'western' idea of liberal democracy - the ideals of individual liberty, freedom of speech, equality of citizenship, representation in the state through periodic elections, and so on. This began seven decades ago when the would-be political leader of Nepal were exposed to Indian independence movement. The second is the emergence and spread of left ideology with its own notion of democracy and how this relates to liberal democracy and how this relates to liberal democracy. The formation of the Communist Party of Nepal, in coincidence with the translation of the Communist Manifesto in early 1950s promoted this notion of democracy as it spreads organisational strength over time. And, third is the appropriation of the concept of democracy for ideologically sustaining 30 year rule of absolute monarchy during the Panchayat era (Bhattrai, 2004, pp. 24-29).

However, the different variants, exhibiting a clear relationship between the state and democracy, propose specific sets of political 
institutions, government programs and procedures. All of these claim to pursue universal democratic ideals including equitable development. In practice, however, the concept of democracy is extended even for justifying anti-democratic ends ranging from corruption, and abuse of authority for fulfilling self-interest to use of violent means for oppression.

Another common feature is that leadership of all actors who hold power to define and implement democracy programs continually come from the same set of social backgrounds; namely Bahun, Chhetri, Thakuri and some Newars. Such imbalanced representation is directly reflected in the state institution, as well as in the civil society sector. The exclusion of the marginalized groups has become institutionalized across the various sectors as networks established by the dominant group expand and function in the country. In recent times, however, a systematic exclusion of the marginalized from participation in public decision-making and perpetuation of inequality and discrimination is being contested and often termed as betrayal of democracy by social movement activists.

Such social movement made possible by a democratic atmosphere is a positive aspect. Until recently, the marginalized groups and ethnic minorities lacked both intellectual resources and freedom to express their views (Lama, 2004). The democracy in Nepal after 1990 has enabled innovative mobilization of social groups for resisting the abuse of state power and asking for alternative forms of democracy. Insisting on their rights as laid out in the very concept of democracy; various social groups including Janajati, Dalit, women and other non-party actors have advanced a considerable political and ideological assertion for new and representative political order. This leads to the recognitions of pluralism as the first and foremost a property of the political system, and more specifically a necessary condition for democracy. Pluralistic democracy therefore, should be characterised by the distribution of effective decision-making power among a wide variety of autonomous groups and institutions coexisting each other.
Niraja Gopal Jayal (2001) in her well researched and elegantly written book, based on her empirical details, comes up with three ostensibly democratic arguments. First the political argument of majoritarianism which chooses as the test of democracy, the numbers of people affected both positively and negatively, and weighs these numbers against each other. This is premised on an assumption of the essential fairness of a political system of representation, where the highest decision-making bodies are elected in accordance with widely accepted democratic procedures, and whose laws are believed to apply uniformly to all citizens (Jayal, 2001, p. 226).

The second argument is overly developmentalist, though no less political than the first. This is the argument of 'public purpose' enabling the state to ask sections of its citizenry to sacrifice some of their rights in order that society 'as a whole' may benefit. These benefits may be far removed from the lives of those making the sacrifice remains tangential (Jayal, 201, p. 227).

The third one is a cultural argument, with clear economic and political overtones. This arguments appeals to the notion of the 'national mainstream', claiming that those who want the tribal to live as they always have, are comprising to keep them out of the national mainstream, culturally and economically, and thus preventing them from enjoying the fruits of development (Jayal, 201, p. 227). Even though, each of these arguments appeals to the democratic principle; the first, through its thoroughgoing majoritarianism; the second, by invoking the notion of the public interest and the common good; and the third, by alluding to the idea of uniform application of laws and, more distantly, to the idea of equal opportunity; none of these arguments, it is significant, invokes the notion of a right to equal respect for all persons, including respect for diverse cultures and ways of life (Jayal, 201, p. 227).

For further clarity, Dreze and Sen (2002) cautiously distinguish between democratic ideals, democratic institutions and democratic practices. For them democratic ideals represent various aspects of the broad ideas of "government of the people, by the people and for the people." They include political characteristics that can be 
seen to be intrinsically important in terms of the objectives of democratic social living, such as freedom of expression, participation of the people in deciding on the factors governing their lives, public accountability of leaders and an equitable distribution of power (Dreze and Sen, 2002, p. 5). Democratic institutions go beyond these basic intents, and include such instrumental arrangements as constitutional rights, effective courts, responsive electoral systems, functioning parliaments and assembling, open free media, and participatory institutions of local governance. Democratic institutions provide opportunities for achieving democratic ideals, how these opportunities are realised is a matter of democratic practices (Dreze and Sen, 2002, p. 5).

\section{Conclusions}

Considering different discourses, 'democracy', in our context, can be conceptualised as the condition where participation and representation of all sections of the population, viz. Dalits, women, ethnic minorities and marginal people in all level of decision-making processes - from local to national- are guaranteed. After all, the use of the word "democracy" occurs neither alone, nor steadily, nor completely; it is, “ethnographically emergent” (Paley, 2002, p. 486).

Finally, the review suggests that democracy (ideals, institutions and practices) is depended upon effective state vis-à-vis strong civil society. Effectiveness of the state and the strength of the civil society, both depend on a common denominator, that is, participation. Quality of participation (pseudo, genuine, etc.) then eventually determines the state of democracy, from the local to national level. Different ethnographic contexts produce different, yet unique, definitions and discourses of democracy; analysis of which portray how a local community are connected with regional and national contexts.

\section{Reference}

Alam, J. (2004). Who Wants Democracy.New Delhi: Orient Longman. Banarjee, M. (2008). 'Democracy, Sacred and Every day: An Ethnographic Case from India', in Paley, J. (ed.) (2008)Democracy: Anthropological Perspectives. Santa Fe: School for Advanced Research Press.

Baral, L.R. (ed.) (2006).Nepal Quest for Participatory Democracy.New Delhi: Adroit Publishers.

Bellamy, B. (2009)."Tradition in Transition: Tharu Traditional Governing System in Post-Conflict Nepal" ISP Collection.Paper. http://digitalcollections.sit.edu/isp_collection/798

Bhattachan, K.B. (1997). 'People/community-Based Development Strategy in Nepal', pp. 100-148, in Krishna B. Bhattachan and Chaitanya Mishra (eds.) Development Practices in Nepal.Kathmandu: Central Department of Sociology and Anthropology, TribhuvanUniversity in co-operation with Friedrich-Ebert-Stiftung (FES), Nepal.

Bhattrai, B.R. (2003). 'The Political Economy of the People's War' in Arjun Karki and DavidSeddon (eds.) The People's War in Nepal: Left Perspective. Delhi: Adroit Publishers.

Bleie, T. (2002).'The Historical Path to Violent Destabilisation in Nepal: Elements of an Exploratory Framework', in MartinScheinin and MarkkuSuksi (eds.) Empowerment, Participation, Accountability and Non-Discrimination: Operationalising a Human Rights-Based Approach to Development.TheHague: KluwerLaw International.

Dhakal, S. (1996).'Bheja as a strategic cultural convention: community resource management in the BarahaMagarat', Occasional Papers in sociology and Anthropology. 5:38-51.

Dhakal, S. Sangroula, K.Bataman, G. (2004). Whose War: Economic and Socio-cultural Impacts of Nepal's Maoist-Government Conflict. Kathmandu: NGO Federation Nepal. 
Dhakal, S. and Chemjong, D.(2007) 'Socio-cultural Institutions of Tharus of Western Tarai, Nepal. (pp.19-33). In Bidya Nath Koirala, Anju Khadka and Rajan Khadka (eds.) Democratic Indigenous Practices of Nepal. Kathmandu: Nepal Centre for Creative Research.

Dhakal, S. and Pokharel, S.(2004).'Local Movements, Political Processes and Transformation of Bhaktapur: A Case Study of Bhaktapur Municipality', draft paper submitted to Loknitit: Institute of Comparative Democracy/SDSA.

Gellner, D.N. (2003). 'Introduction: Transformations of the Nepalese State', in David N. Gellner (ed.) Resistance and the State: Nepalese Experience, New Delhi: Social Science Press.

Glassman, R.M.(1986). Democracy and Despotism in Primitive Society: A Neo-Weberian Approach to Political Theory'. Vol. 1. New York: Associated Faculty Press.

Gurung, H.(2004). 'Affirmative action in Nepalese Context'. Paper presented at National Dialogue in Affirmative Action and Electoral System in Nepal. Kathmandu, September 27-28.

Hachhethu, K. (2004). Municipality leadership and governance: A case study of Bhaktapur' Chapter 2, inNepal: Local leadership \& governance, Delhi: Adroit Publishers.

Hofer, A.(1997). The Caste Hierarchy and the State in Nepal: A Study of Muluki Ain of 1854. Innsbruk: UniversitatsverlagWagner.

Jayal, N.G. (2001).Democracy and the State: Welfare, Secularism and Development in Contemporary India.New Delhi. Oxford University Press.

Joas, H.(1996). The Creativity of Action.Chicago: The University of Chicago Press.

Karki, A. and Seddon, D. (2003) The Peoples War in Nepal Left Perspective'. Delhi: Adroit Publishers.

Khanal, K.(2004a).'Village leadership and governance: A case study of two VDCs of Kathmandu district, Chapter 3 inNepal: Local leadership \& governance, Delhi: Adroit Publishers.

Khanal, K.(2004b). 'Consideration of possible model of Proportional Representation for Nepal'. Paper presented at National
Dialogue in Affirmative Action and Electoral System in Nepal. Kathmandu, September 27-28.

Krämer, K.H. (2003).'How Representative is the Nepali State?' In David Gellner (ed.) Resistance and the State: Nepalese Experience. New Delhi: Social Science Press.

Kumar, D. (2005). 'Proximate Causes on Conflict in Nepal' in Contribution to Nepalese studies.Vol. 32.No. 1. (pp. 51-92). Kathmandu: Centre for Nepal and Asian Studies.

Lama, M.S. (2004)..Democracy in Nepal, Discourses and Practices: A Qualitative Assessment. Paper submitted to Centre for the Study of Developing Societies, Delhi. (The paper is later published entitled 'The Working of Democracy', in Seminar. Vol. 548 April 2005).

Lawoti, M. (2005).Towards a Democratic Nepal: Inclusive Political Institutions for a Multicultural Society. New Delhi, Sage Publication/Kathmandu, Mandala Book Point.

Messerchmidt, D.and Gurung, N. J. (1974)."Parallel trade and innovation in central Nepal: The cases of the Gurung and Thakali Subbas compared," in Contributions to the anthropology of Nepal. Edited by Christoph von FiurerHaimendorf, pp. 197-221. Warminster, England: Aris and Phillips. [DAM]

Messerchmidt, D.(1973). "Dhikur: Rotating credit associations in Nepal," in The Himalayan Interface. Edited by James Fischer. The Hague: Mouton. In press. [DAM]

Mishra, C. (2004). 'Locating the Causes of Maoist Struggle', in Studies in Nepali History and Society. Vol.9 No.1. (pp. 3-56). Kathmandu: Mandala Book Point.

Muni, S.D.(2003).Maoist Insurgency in Nepal.New Delhi: Observer Research Foundation.

Neupane, G.(2003). 'The Maoist Movement in Nepal: A Class Perspective', in Arjun Karki and David Seddon (eds.) The People's War in Nepal: Left Perspective.Delhi: Adroit Publishers. 
Paff-Czarnecka(1997). 'Vestiges and Visions: Cultural Change in the Process of Nation-Building in Nepal', in David N. Gellner, Joanna Pfaff-Czarnecka, \& John Whelpton (eds.), Nationalism and Ethnicity in an Hindu Kingdom: The Political of Culture in Contemporary Nepal. Amsterdam: Hardwood.

Paley, J. (ed.) (2008).Democracy: Anthropological Perspectives. Santa Fe: School for Advanced Research Press. 'Introduction'.In Paley, (ed.)(2008).Democracy:Anthropological Perspectives. Santa Fe: School for Advanced Research Press.

. 'Participatory Democracy, Transparency and Good Governance in Ecuador: Why Have Social Movement Organization at All?' In, Paley, J. (ed.)(2008).Democracy: Anthropological Perspectives. Santa Fe: School for Advanced Research Press.

Paley, J.(2004). 'Accountable Democracy: Citizens' impact on public decision making in postdictatorship Chile. American Ethnologists. Vol.31, Issue 4 (pp. 497-513).

Paley, J.(2002). 'Towards an Anthropology of Democracy'.Annual Review of Anthropology 2002 (31): 469-96.

Philipson, L.(2002)Conflict in Nepal: Perspectives on the Maoist Movement. Centre for the Study of Global Governance, LondonSchool of Economics and Political Science.

Regmi, M.C. (1976). Landownership in Nepal. Berkely: University of California Press.

Schemiel, Y. (2000). International Political Science Review (2000), Vol. 21, No. 2, 99-120.

Sen, A. and JeanDerez (1999).The Amartya Sen \&JeanDrezeOmnibus.New Delhi: OxfordUniversity Press.

Sharma, P. R. (2004). The State and Society in Nepal: Historical Foundations adn Contemporary Trends. Kathmandu: Himal Books.
Sharma, P.R. (2054 BS).Kul, Bhoomi ra Rajya: Nepal Upatyakako Purva-Madhyakaalik Samajik Adhayan (Nep). Kathmandu: CNAS

Thapa, D. (ed.)(2003). Understanding the Maoist Movement in Nepal.Kathmandu: MartinChautari.

Thapa, D. and Sijapati, B.(2003).A Kingdom Under Siege: Nepal's Maoist Insurgency, 1996 to 2003.Kathmandu: the printhouse.

Whelpton, J.(2005). A History of Nepal.CambridgeUniversity Press

Young, I.M.(2000). Inclusion and Democracy' Oxford: Oxford University Press. 